OPEN ACCESS

Edited by: Kian Fan Chung, Imperial College London, United Kingdom

Reviewed by:

Rene Lutter,

University of Amsterdam,

Netherlands

Laurent Pierre Nicod, University of Lausanne,

Switzerland

*Correspondence: Giorgio Walter Canonica canonica@unige.it

Specialty section:

This article was submitted

to Pulmonary Medicine,

a section of the journal

Frontiers in Medicine

Received: 14 October 2016

Accepted: 25 July 2017

Published: 31 August 2017

Citation:

Bagnasco D, Ferrando $M$ Varricchi G, Puggioni F, Passalacqua $G$ and Canonica GW (2017) Anti-Interleukin 5 (IL-5) and IL-5Ra Biological Drugs: Efficacy, Safety, and Future Perspectives in

Severe Eosinophilic Asthma.

Front. Med. 4:135

doi: 10.3389/fmed.2017.00135

\section{Anti-Interleukin 5 (IL-5) and IL-5Ra Biological Drugs: Efficacy, Safety, and Future Perspectives in Severe Eosinophilic Asthma}

\author{
Diego Bagnasco', Matteo Ferrando ${ }^{1}$, Gilda Varricchi², Francesca Puggioni ${ }^{3}$, \\ Giovanni Passalacqua ${ }^{1}$ and Giorgio Walter Canonica ${ }^{1,3 *}$
}

\begin{abstract}
'Allergy and Respiratory Diseases, DIMI Department of Internal Medicine, University of Genoa, IRCCS AOU San Martino-IST, Genoa, Italy, ${ }^{2}$ Department of Translational Medical Sciences, Division of Clinical Immunology and Allergy, University of Naples Federico II, Naples, Italy, ${ }^{3}$ Department of Internal Medicine, Respiratory Disease Clinic, IRCCS Humanitas Clinical and Research Center, Humanitas University, Milan, Italy
\end{abstract}

The definition of asthma has changed considerably in recent years, to the extent that asthma is no longer considered a single disease but a heterogeneous disorder that includes several phenotypes and, possibly, endotypes. A more detailed analysis of the immunological mechanisms underlying the pathogenesis of asthma shows interleukin 5 (IL-5) to be a crucial cytokine in several asthma phenotypes. In fact, IL-5 exerts selective action on eosinophils, which, in turn, sustain airway inflammation and worsen asthma symptoms and control. Clinical trials have shown drugs targeting IL-5 or its receptor alpha subunit (IL-5Ra) to be a promising therapeutic approach to severe asthma, whose characteristics render standard therapy of little use: systemic corticosteroids only partially control the disease and have well-known adverse effects, and omalizumab is used for allergic subtypes. Analysis of the design process of clinical trials reveals the importance of patient selection, taking into account both clinical data (e.g., exacerbations, lung function, and quality of life) and biomarkers (e.g., eosinophils, which are predictive of therapeutic response).

Keywords: interleukin 5, precision medicine, personalized medicine, severe asthma, monoclonal antibodies, biomarkers, eosinophils, safety

\section{INTRODUCTION}

The definition of asthma has changed considerably during the last decade, to the extent that, rather than a single disease based on a reversible airway obstruction, asthma is now considered a heterogeneous disease with several phenotypes (1). The turning point was the sharp division of bronchial asthma into two large groups based on the expression of the type 2 helper T lymphocyte $\left(\mathrm{T}_{\mathrm{H}} 2\right)$ genes underlying the disease, namely, $\mathrm{T}_{\mathrm{H}} 2$-high and $\mathrm{T}_{\mathrm{H}}$ 2-low asthma (2). This distinction made it easier to evaluate the disease in terms of its pathogenic mechanisms and of the drugs administered at different levels of the inflammatory cascade. Evidence of the importance of this distinction in allergy and asthma can be seen in the fact that eosinophilic inflammation led researchers to intervene directly in pathogenic mechanisms to better control the disease and reduce the number of exacerbations. The demonstration of a close link between eosinophils and interleukin (IL) 5 shifted attention to this cytokine and led to the development of new drugs able to act directly on interleukin 5 (IL-5) and its specific receptor $\alpha$-subunit (IL-5Ra). 


\section{THE $T_{\mathrm{H}} 2$-HIGH PHENOTYPE: THE DISCOVERY OF A SPECIAL KIND OF INFLAMMATION}

The clinical evidence of heterogeneity in asthmatic patients in terms of disease severity, age at onset, allergic sensitization, response to treatments, and natural history prompted researchers to better understand the pathophysiological mechanisms underlying asthma by subdividing patients into various phenotypes $(3,4)$. Different approaches have been proposed for dividing the groups. The Severe Asthma Research Program (SARP) study identified four asthma clusters based on age at onset, airflow limitation, comorbidities, and lung function (5). A hierarchical cluster analysis performed in the SARP study classified asthmatic patients into five groups according to age at onset, atopy, use of corticosteroids, and lung function (6). Schatz and colleagues performed a post hoc analysis, "The Epidemiology and Natural History of Asthma: Outcomes and Treatment Regimens" (TENOR) study, which confirmed the existence of various clusters and phenotypes in severe asthmatic adolescents and adults (7). Furthermore, in a study based on a molecular approach, Woodruff and colleagues discovered that IL-13 can stimulate the expression of chloride channel, calcium-activated, family member 1 (CLCA1), periostin, serine peptidase inhibitor, clade B (ovalbumin), and serpin family B member 2 (serpinB2), all of which are overexpressed in asthmatic patients (8). A further step forward in the knowledge of this disease was made observing that cytokines involved in its pathogenesis were not the same in all asthmatic patients, therefore allowing to subdivide them in two different groups according to the presence, or the absence, of $\mathrm{T}_{\mathrm{H}} 2$ inflammation. $\mathrm{T}_{\mathrm{H}} 2$-high patients are characterized by the expression of IL-5 and IL-13, airway hyperresponsiveness, responsiveness to inhaled corticosteroids (ICS), high serum IgE levels, and blood and airway eosinophilia. In contrast, the $\mathrm{T}_{\mathrm{H}}$ 2-low (healthy) group does not present these characteristics $(2,3,9)$. In the $\mathrm{T}_{\mathrm{H}} 2$-high phenotype, which is characterized by eosinophilic inflammation, IL-5 is a central cytokine, with a key role in eosinophil differentiation, survival, activation $(10,11)$, and migration in the lungs $(12,13)$. In the $\mathrm{T}_{\mathrm{H}} 2$-low phenotype, on the other hand, the association between inflammation and the action of the abovementioned cytokines is less well defined, and the mechanisms underlying the disease in these patients remain little known $(14,15)$.

\section{INTERLEUKIN 5}

Interleukin 5 is a 13 -amino acid protein that forms a $52-\mathrm{kDa}$ homodimer related to both granulocyte-macrophage colonystimulating factor (GM-CSF) and IL-3. It binds to a heterodimer receptor on eosinophils formed by the $\alpha$ subunit (IL-5Ra) and the $\beta c$ subunit, which is shared with the IL- 3 and GM-CSF receptors (16). IL-5 is synthesized and secreted by eosinophils, $\mathrm{T}_{\mathrm{H}} 2$ cells, mast cells, CD34+ progenitor cells, natural killer (NK) T cells, and type 2 innate lymphoid cells (ILC2) $(10,17)$. In asthmatic patients, CD4 $\mathrm{T}_{\mathrm{H}} 2$ cells, CD34+ cells, mast cells, and eosinophils are major factors in the production of IL-5. Together with IL-3 and GM-CSF, IL-5 plays an essential role (16) in inflammation and the allergic response, favoring the production, maturation, proliferation, recruitment, differentiation, and survival of eosinophils $(18,19)$. In addition, IL-5 in bone marrow favors the differentiation of several CD34+ cells into eosinophils (20). Strikingly, IL-5 is associated not only with active inflammation but also with airway remodeling processes (21). Moreover, IL-5 can also affect basophil and mast cell activity, owing to the common expression of several crucial receptors (IL-5R, IL-3R, IL-4R, IL-2Ra, and GM-CSF) in these cells (22).

ILCs are characterized by their lack of T-cell and B-cell receptors (TCRs and BCRs, respectively) (23) and associated with tissue repair (24), the duration of the initial immune response to microorganisms (25), and control of proliferation of commensal microorganisms (26). These cells are able to produce cytokines quickly in response to chemical and environmental signals (i.e., IL-25, IL-33, thymic stromal lymphopoietin, and IL-1 $\beta$ ) and can act on ILC growth and differentiation (27). ILCs can be subdivided into three different categories (ILC1s, ILC2s, and ILC3s), according to the production and expression of cytokines and transcription factors (28). Further differentiation into the different subtypes of ILCs depends on the phenotypic and functional characteristics of the T-cell subset and the expression of regulatory genes, so that ILC1s are linked to $T_{H} 1$ inflammation, ILC2s to $\mathrm{T}_{\mathrm{H}} 2$-induced inflammation, and ILC 3 to $\mathrm{T}_{\mathrm{H}} 17$ and $\mathrm{T}_{\mathrm{H}} 22$ inflammation (29). Furthermore, the transcription of several genes, including GATA-binding protein 3 (GATA3) (30) and retinoic acid receptor-related orphan receptor- $\alpha$ for ILC2s (ROR $\alpha)$ (31), is related to the differentiation of the ILC precursor in ILC2s. In lung tissue, they have a role in production of IL-5, suggesting a possible effect on the development, maturation, and action of eosinophils. The discovery that ILC2s play a role in the development and maturation of $\mathrm{T}_{\mathrm{H}} 2$ cells makes them interesting as a possible future therapeutic target in $\mathrm{T}_{\mathrm{H}} 2$-high patients $(29,32)$.

\section{EOSINOPHILS IN ASTHMA}

Interleukin 5 acts on several types of cells. However, in airway disease in general and asthma in particular, eosinophils remain its primary target. Many papers support the pleiotropic effects of eosinophils in several asthma phenotypes (33-36). First, they play a role in the innate response to exogenous agents in airways, and second, they play a role in the modulation of the adaptive immune cascade, making them important cells in the body's defense system. Eosinophils damage tissues by degranulating and releasing reactive oxygen species and cysteinyl leukotrienes (LT) (37). In vivo studies have demonstrated that exposing circulating eosinophils to IL-5 can activate their degranulation processes (38). IL-5 also stimulates eosinophilic airway inflammation and airway hyperresponsiveness (39). Eosinophil secretory granules contain not only histaminase and arylsulfatase, which are directly involved in allergic reactions, but also eosinophil peroxidase, eosinophil cationic protein, major basic protein, and eosinophil-derived neurotoxin. In addition, during degranulation, eosinophils produce IL-5 and LT such as LTC4, LTD4, and LTE4 (40), which are involved in bronchoconstriction and secretion of mucus $(16,41)$, thus resulting in intensification of airway narrowing. 
Severe forms of eosinophilic asthma are characterized by intense symptoms associated with poor disease control and high eosinophil levels in blood and sputum (42). Eosinophils also play a role in the development of asthma by thickening the reticular basement membrane through production of several factors (i.e., TGF-b, VEGF, MMP-9, TIMP-1, and IL-13) (43) (Figure 1).

\section{FROM EOSINOPHILS TO MONOCLONAL ANTIBODIES}

Given the crucial role of IL-5 in eosinopoiesis in bone marrow and eosinophil recruitment and survival in peripheral tissues, several trials evaluated the possibility of using antibodies that target this cytokine $(44,45)$ or its receptor alpha subunit $(46,47)$ to regulate eosinophilic inflammation in uncontrolled and symptomatic asthmatic patients with high eosinophil counts.

\section{Mepolizumab}

Mepolizumab is a humanized monoclonal $N$-glycosylated IgG1/k antibody that binds the $\alpha$-chain of IL-5, thus preventing its association with the $\alpha$ subunit of the IL-5 receptor (48). Mepolizumab has been tested in several diseases, including severe asthma, atopic dermatitis, and nasal polyposis. Clinical trials were also conducted to assess its direct action on eosinophilic inflammation in patients with eosinophilic esophagitis, hypereosinophilic syndromes, and eosinophilic granulomatosis with polyangiitis (34, 35) (NCT02020889, NCT00266565, NCT00716651, and NCT00527566) and chronic obstructive pulmonary disease (COPD) (NCT01463644, NCT02105961, and NCT02105948) (49).

The first evaluation of the possible effect of mepolizumab was carried out in a population of cynomolgus monkeys. Hart et al. observed a significant reduction in both blood and airway eosinophilia after a single dose (50).

Since the results of mepolizumab in asthmatic patients are generally favorable, it was recently approved by the United States FDA with the trade name Nucala ${ }^{\circledR}$ as add-on therapy (100 mg subcutaneously every 4 weeks) in patients aged $\geq 12$ years with severe asthmatic eosinophilia. ${ }^{1,2}$ Furthermore, mepolizumab was

'http://www.fda.gov/NewsEvents/Newsroom/PressAnnouncements/ucm471031. htm.

${ }^{2}$ http://www.fda.gov/newsevents/newsroom/pressannouncements/ucm491980.htm.

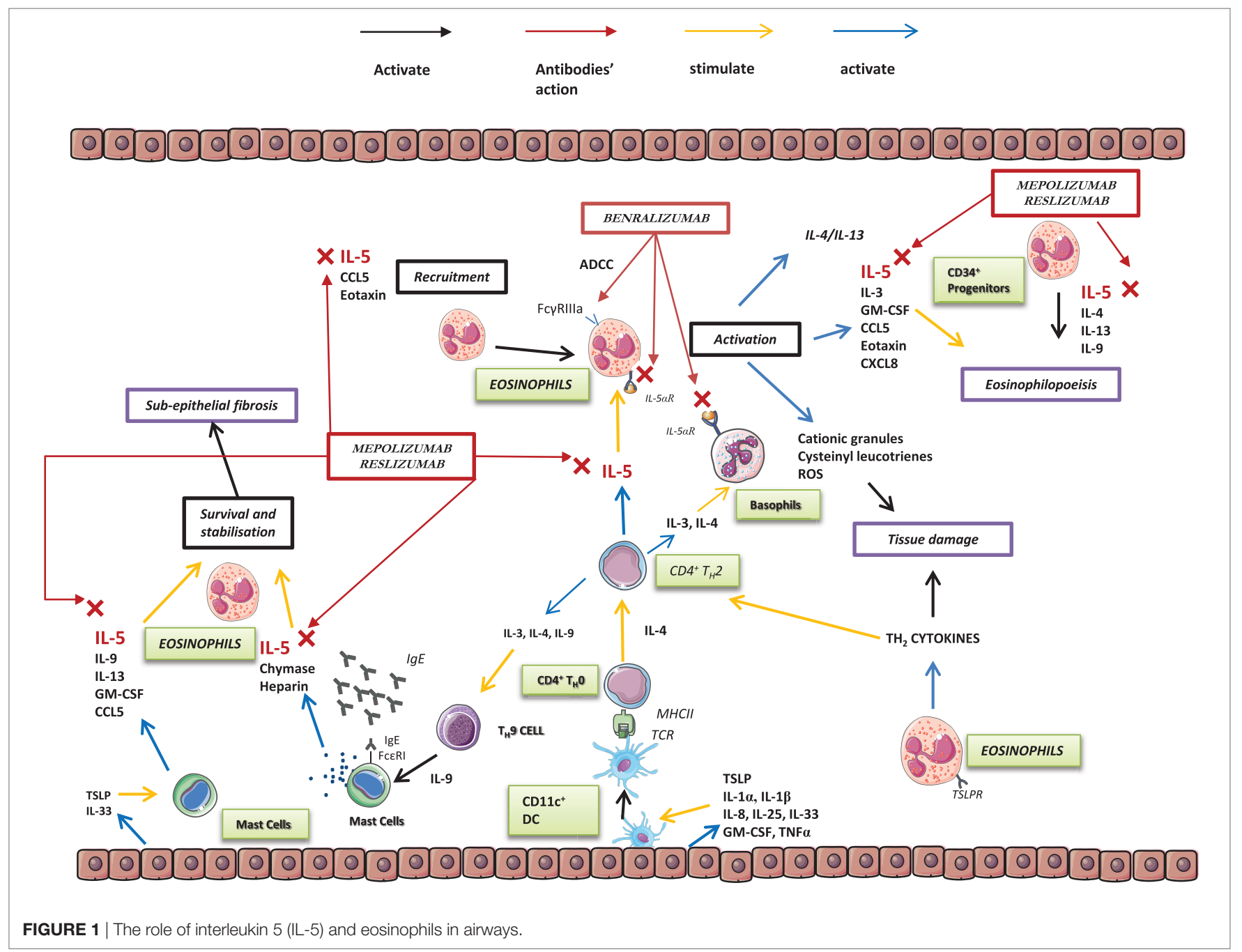


recently approved by the European Medicines Agency Committee for Medicinal Products for Human Use. ${ }^{3}$

\section{Reslizumab}

Reslizumab is an IgG4/k humanized monoclonal antibody (51) that blocks circulating IL-5 and prevents it from binding to eosinophil receptors. Several clinical trials have evaluated the use of reslizumab in asthma, hypereosinophilia after administration of diethylcarbamazine for treatment of Loa-Loa infection (NCT01111305), and eosinophilic esophagitis (NCT00635089) (52). Reslizumab was recently approved for intravenous administration in the USA in patients aged $\geq 18$ years as add-on therapy for severe uncontrolled eosinophilic asthma (see text footnote 2).

\section{Benralizumab}

Benralizumab differs from the abovementioned biologicals, since it targets the IL-5Ra subunit (53), which is expressed in eosinophils and basophils (54). Consequently, the effects of benralizumab were demonstrated not only for eosinophils but also for basophils. The drug induced apoptosis through antibody-dependent cell-mediated cytotoxicity (ADCC), where NK cells target cells and induce their cytotoxic action (55). The mechanism of action of benralizumab differs from that of other anti-IL-5 monoclonal antibodies, first because of its action on the receptor and second because of its higher affinity to human FcyRIIIa, resulting in enhanced ADCC action (56). In fact, through its enhanced ADCC activity, benralizumab reduces levels of circulating eosinophils and basophils (53). Therefore, it has been proposed as a biological drug not only in eosinophilic asthma but also in COPD (57), hypereosinophilic syndrome, and chronic rhinosinusitis.

\section{Clinical Results}

Preclinical studies on monkeys, guinea pigs, and mice reported variable results for eosinophils in blood and bronchoalveolar lavage fluid, airway hyperresponsiveness, and pulmonary resistance (58) but showed a significant reduction in both blood and sputum eosinophilia in treated animals (59). Leckie et al. performed a double-blind, randomized, placebo-controlled study to test a single dose of anti-IL-5 antibody ( 2.5 or $10 \mathrm{mg} / \mathrm{kg}$ ) in 24 nonsmoking male patients with mild allergic asthma. On days 8 and 29 after administration, all patients underwent a histamine challenge, an inhaled allergen challenge, and sputum induction. The results demonstrate that infusion of anti-IL-5 antibody decreases blood eosinophil levels for up to 4 weeks and sputum levels at 4 weeks, thus leading the authors to consider this antibody a possible new approach in eosinophilic asthma (60). Further studies on this biological drug did not reveal significant variations in clinical parameters (e.g., airway hyperresponsiveness, $\mathrm{FEV}_{1}$, and peak flow recordings) between the mepolizumab- and placebotreated groups. Flood-Page and colleagues treated 24 patients with 3 doses of $750 \mathrm{mg}$ of mepolizumab at 0,4 , and 8 weeks and found non-significant variations in airway hyperresponsiveness,

${ }^{3}$ http://www.ema.europa.eu/ema/index.jsp?curl=pages/medicines/human/medicines/003860/human_med_001933.jsp\&mid=WC0b01ac058001d124. lung function $\left(\mathrm{FEV}_{1}\right)$, the late asthmatic reaction to inhaled allergen, and peak flow recordings between placebo- and mepolizumab-treated groups, concluding that the role of eosinophils remains uncertain in asthma (61). As an explanation, the authors hypothesized that the effect of mepolizumab could not sufficiently deplete airway eosinophils and consequently act on respiratory function. Several hypotheses have been suggested by other authors. Kay and Menzies-Gow considered the possibility of different levels of depletion of eosinophils in bone marrow and airways, assuming that the antibody could not penetrate tissue or act systemically to reach bone marrow and bronchial mucosa (62). A second hypothesis allowed for the possibility that other cytokine mechanisms, such as IL-3 and GM-CSF, could overcome the mechanism blocked by mepolizumab. The authors therefore evaluated mepolizumab in more characteristic asthmatic patients to better identify subgroups of responders (63). In fact, subsequent studies were restricted to patients with severe asthma and high blood eosinophil counts and showed a significant difference in the exacerbation rate between actively treated patients and patients receiving placebo. In the first large-scale trial in this area (DREAM study), the reduction in exacerbations was significantly greater in the mepolizumab group than in the placebo group ( $48 \%$ for the $75-\mathrm{mg}$ dose, $39 \%$ for the $250-\mathrm{mg}$ dose, and $52 \%$ for the 750-mg dose) (45).

The steroid-reducing effects of mepolizumab were evaluated in the SIRIUS study, where 135 patients with severe eosinophilic asthma were treated with $100 \mathrm{mg}$ of subcutaneous anti-IL- 5 antibody or placebo every 4 weeks over a period of 20 weeks. After the period of optimization of the dose of oral corticosteroids (OCS), patients started to receive the drug or placebo and reduce their intake of OCS during the period from week 4 to 20. During the second part of the study (maintenance phase), no further adjustments were made to OCS doses. Eligible patients had to have undergone at least 6 months of maintenance OCS therapy (5-35 mg of prednisone or equivalent) and had an eosinophil count of $\geq 300 / \mu \mathrm{L}$ during the previous year and $\geq 150 / \mu \mathrm{L}$ during the optimization phase. The results show that patients receiving mepolizumab were 2.65 times more likely to reduce the dose of OCS than patients receiving placebo (95\% CI, 1.25-4.56; $P=0.008$ ), with a reduction in the frequency of exacerbations of $32 \%$ and an improvement in quality of life measured according to the Asthma Control Questionnaire 5 (ACQ-5) score (64).

In the MENSA study, mepolizumab was administered at $75 \mathrm{mg}$ intravenously or $100 \mathrm{mg}$ subcutaneously to 385 asthmatic patients aged between 12 and 82 years with recurrent exacerbations. In the first group, who received intravenous mepolizumab, the exacerbation rate decreased by $32 \%$, whereas in the second group, who received mepolizumab subcutaneously, the rate fell by $53 \%$, that is, significantly higher in patients receiving mepolizumab subcutaneously (44). In a further two major trials, the number of exacerbations was significantly reduced in patients receiving mepolizumab $(45,65)$. As previously described, the reduction in the frequency of exacerbations in treated patients is certainly one of the most interesting results from clinical trials. After examining the results of clinical trials with mepolizumab in severe asthmatic patients, the Cochrane Collaboration concluded that the best results for reduction in the exacerbation rate were 
seen in patients with elevated blood eosinophil counts. In fact, two studies, MENSA and DREAM, demonstrated that a significant clinical reduction in exacerbation rates occurred in hypereosinophilic patients (RR, 0.52; 95\% CI, 0.43-0.64; participants $=690$ ). Nevertheless, an analysis of four studies with heterogeneous serum eosinophil levels showed a non-significant difference between the mepolizumab group and the placebo group in terms of decreased frequency of exacerbations (RR, 0.67; 95\% CI, 0.34-1.31; participants $=468 ; I 2=59 \%)(66)$. Another meta-analysis of the efficacy of mepolizumab in asthmatic patients demonstrated that patients in the placebo group had more exacerbations (173 of 324; $53.4 \%$ ) during the study than the mepolizumab group (91 of 310 ; $29.3 \%)$. The pooled analysis evidenced a significant reduction in the risk of exacerbation $(0.30$; 95\% CI, 0.13-0.67, $P=0.004)(67)$. The most recent study on mepolizumab (MUSCA) evaluated the effect of the drug on health-related quality of life (HRQOL). This randomized, double-blind, placebo-controlled, parallel-group, multicenter, phase $3 \mathrm{~b}$ trial included 274 patients in the mepolizumab arm and 277 in the placebo arm, both with a history of at least two exacerbations requiring treatment during the previous year, despite daily use of high-dose ICS combined with other controller medicines. A significant change was observed in the St. George's Respiratory Questionnaire score at week 24, with an improvement in symptoms and HRQoL in patients receiving mepolizumab, compared with those receiving placebo (68).

The other IL-5 antagonist, reslizumab, also displayed encouraging results. Castro et al. reported a significant reduction in asthma exacerbation rates in a phase 3 study of patients aged 12-65 years with asthma that was inadequately controlled using medium-high doses of ICS. Blood eosinophil counts were $>400 / \mu \mathrm{L}$, and patients had experienced one or more exacerbations in the previous year (69).

The reduction in the exacerbation rate was also the primary outcome measure in clinical trials investigating the use of benralizumab, an anti-IL-5Ra subunit monoclonal antibody. Nowak and colleagues reported the results of a phase two, randomized, double-blind, placebo-controlled study, where a single intravenous dose of 0.3 or $1 \mathrm{mg} / \mathrm{kg}$ of benralizumab or placebo was administered to patients who presented at the emergency department because of asthma exacerbation. The aim of this study was to evaluate whether a single dose of an anti IL-5Ra agent could reduce the future risk of exacerbation in patients who had recently experienced an acute episode of asthma. The authors concluded that benralizumab reduced asthma exacerbation rates by $49 \%$ ( 3.59 vs $1.82 ; P=0.01)$ and the number of exacerbations requiring admission to hospital by $60 \%$ ( 1.62 vs 0.65 ; $P=0.02$ ) in both groups (46). Interestingly, in a double-blind phase 2 study involving adult patients with uncontrolled asthma despite therapy with medium-high doses of ICS and long-acting $\beta$-agonists who had had between two and six exacerbations in the previous year, Castro et al. reported a relevant reduction in exacerbations in patients with a peripheral blood eosinophil count of at least 300/ $\mu \mathrm{L}$ (70). On the other hand, improvements in lung function with anti-IL-5 or anti IL-5Ra monoclonal antibodies were less relevant $(44,45,65,70,71)$. More recently, Bleecker and colleagues described the results of the SIROCCO study, a double-blind, parallel-group, placebo-controlled phase 3 clinical trial involving 12- to 75-year-old asthmatic patients with at least two exacerbations in the previous year despite optimal inhaled therapy. Patients were divided into two parallel arms. In the first, 400 patients received benralizumab $30 \mathrm{mg}$ every 4 weeks and 398 patients every 8 weeks. In the second, 275 patients received $30 \mathrm{mg}$ every 4 weeks and 267 patients every 8 weeks. The results confirmed the efficacy of benralizumab in severe eosinophilic asthma in terms of exacerbation and safety (72). It is noteworthy that similar results in terms of reduction in the frequency of exacerbations were obtained in the CALIMA study, which evaluated the efficacy of administering $30 \mathrm{mg}$ of benralizumab every 4 or 8 weeks (47).

Changes in exacerbation rates have been shown to be favorable and encouraging overall, although improvements in $\mathrm{FEV}_{1}$ and in HRQOL did not reach statistical significance. Some studies showed improved pulmonary function $(44,64,70,71)$, whereas others did not $(45,46,63,65)$, and this variability in results was also described for HRQOL in other clinical studies $(45,46,64,65,70,71)$.

The fact that the patients enrolled in early trials did not show a significant reduction in the number of exacerbations could be due to two factors. First, in the case of baseline circulating eosinophilia, Castro et al. (69) found that the eosinophil cutoff value at baseline was higher than that described by Leckie and colleagues (60). Second, the exacerbation rate of the active population receiving the investigational product may have been different. In early trials, patients had mild-to-moderate asthma and a low number of asthma exacerbations in the previous year. In addition, the reduction appears less significant than that of active groups in later studies, which were characterized by higher baseline exacerbation rates and a more consistent reduction in the frequency of asthma flares (Table 1).

\section{Safety}

The safety data provided by clinical trials are generally reassuring, at least in the populations included (74). All IL-5 antagonists seem to be well tolerated. No deaths or severe reactions were reported for either intravenous or subcutaneous administration. The serious adverse events described in the trials with intravenous mepolizumab (hydrocephalus/cerebrovascular disorder, constipation, gastrointestinal disturbance, and asthma exacerbation) were not considered treatment-related by clinicians $(63,73)$. The SIRIUS study reported adverse events in $83 \%$ of patients receiving the drug subcutaneously and in $92 \%$ in the placebo group (see text footnote 1). The most common adverse events reported were headache, injection-site reactions, and nasopharyngitis, with similar frequencies in the active and placebo groups. Asthma exacerbations were reported in 3\% of mepolizumab patients and in $12 \%$ of placebo patients (64). In one of the mepolizumab studies (MENSA), the frequency of adverse events was similar in all three groups: $84 \%$ in patients receiving intravenous mepolizumab, $78 \%$ in the subcutaneous group, and $83 \%$ in the placebo group. The reduction was significant if the events that were judged drug-related by clinicians (17\% intravenous, $20 \%$ subcutaneous, and $16 \%$ placebo) are taken into account (44). Once again, the most common adverse events reported were nasopharyngitis, injection-site reactions, headache, and upper respiratory tract 
TABLE 1 | Clinical trials on anti-interleukin 5 (IL-5) and IL-5Ra antagonists: main results and safety findings.

\begin{tabular}{|c|c|c|c|c|}
\hline Reference; study & Exacerbations & Other endpoints & Common adverse events & Serious adverse events \\
\hline \multicolumn{5}{|l|}{ MEPOLIZUMAB } \\
\hline $\begin{array}{l}\text { Chupp et al. (68); } \\
\text { MUSCA study }\end{array}$ & Improvement in QoL & $\begin{array}{l}\text { 仓 } \mathrm{FEV}_{1} \text { (176 mL in } \\
\text { mepolizumab group) } \\
\text { 』 Exacerbations }\end{array}$ & $\begin{array}{l}\text { Headache, nasopharyngitis, back } \\
\text { pain, urticaria, arthralgia, arrhythmias, } \\
\text { injection-site reactions }\end{array}$ & $\begin{array}{l}5 \% \text { of patients in mepolizumab group has } \\
\text { serious adverse events (asthma, systemic } \\
\text { reactions) }\end{array}$ \\
\hline $\begin{array}{l}\text { Ortega et al. (44); } \\
\text { MENSA study }\end{array}$ & $\begin{array}{l}\text { ת Exacerbations (with } \\
\text { intravenous medication, } \\
47 \% \text {; with subcutaneous } \\
\text { administration, } 53 \% \text { ) }\end{array}$ & $\begin{array}{l}\text { 仓 FEV } 1 \text { (100 mL intravenous } \\
\text { administration, } 98 \mathrm{~mL} \\
\text { subcutaneous administration) }\end{array}$ & $\begin{array}{l}\text { Nasopharyngitis, upper respiratory tract } \\
\text { infection, and headache }\end{array}$ & $\begin{array}{l}\text { Incidence of } 7 \% \text { in intravenous group, } 8 \% \\
\text { in subcutaneous, } 14 \% \text { in placebo }\end{array}$ \\
\hline $\begin{array}{l}\text { Bel et al. (64); SIRIUS } \\
\text { study }\end{array}$ & ת Exacerbations (32\%) & $\begin{array}{l}\text { Improvement in Asthma } \\
\text { Control Questionnaire } 5 \text { score }\end{array}$ & $\begin{array}{l}\text { Headache, nasopharyngitis, injection- } \\
\text { site reaction }\end{array}$ & $\begin{array}{l}\text { Asthma exacerbations, pneumonia } \\
\text { (both in placebo group) }\end{array}$ \\
\hline $\begin{array}{l}\text { Pavord et al. (45); } \\
\text { DREAM study }\end{array}$ & $\begin{array}{l}\text { ת Exacerbations ( } 48 \% \\
\text { with } 75-\mathrm{mg} \text { dose and } \\
39 \% \text { with 250-mg dose) }\end{array}$ & $\begin{array}{l}\text { No change in } \mathrm{FEV}_{1} \\
\text { No change in } \mathrm{ACQ} \text { scores }\end{array}$ & $\begin{array}{l}\text { Headache, nasopharyngitis, infusion- } \\
\text { related reaction }\end{array}$ & $\begin{array}{l}3 \text { deaths ( } 1 \text { septic shock after acute } \\
\text { pancreatitis, fatal asthma attack, } \\
\text { suicide) }\end{array}$ \\
\hline Nair et al. (73) & 凤 Exacerbations & $\begin{array}{l}\text { ת Eosinophil count (in sputum } \\
\text { and blood samples) }\end{array}$ & $\begin{array}{l}1 \text { patient with shortness of breath } \\
\text { (heart failure-related), } 1 \text { patient with } \\
\text { aches and tiredness }\end{array}$ & $\begin{array}{l}\text { No drug-related events recorded } \\
1 \text { death in placebo group }\end{array}$ \\
\hline Haldar et al. (65) & $\begin{array}{l}\text { ת Exacerbations } \\
\text { ( } 2.0 \text { vs. } 3.4 \text { drug/ } \\
\text { placebo) }\end{array}$ & $\begin{array}{l}\text { Improvement in AQLQ score } \\
\text { ת Eosinophil count (in sputum } \\
\text { and blood samples) } \\
\text { No change in } \mathrm{FEV}_{1}\end{array}$ & $\begin{array}{l}\text { Facial flushing, rash, pruritus, erectile or } \\
\text { ejaculatory dysfunction, fatigue }\end{array}$ & Severe acute asthma \\
\hline Flood-Page et al. (63) & $\begin{array}{l}\text { Reduction at higher } \\
\text { doses of drug }\end{array}$ & $\begin{array}{l}\text { No improvement in lung } \\
\text { function or symptoms }\end{array}$ & $\begin{array}{l}\text { Upper respiratory tract infection, } \\
\text { asthma, headache, rhinitis, bronchitis, } \\
\text { sinusitis, viral infection, injury, back } \\
\text { pain, nausea, and pharyngitis }\end{array}$ & $\begin{array}{l}250 \text { mg (hydrocephalus/cerebrovascular } \\
\text { disorder, constipation, and gastrointestinal } \\
\text { disturbance), } \\
750 \text { mg (asthma exacerbation) }\end{array}$ \\
\hline \multicolumn{5}{|l|}{ RESLIZUMAB } \\
\hline Castro et al. (69) & 凡ู Exacerbations & & $\begin{array}{l}\text { Worsening of asthma symptoms, } \\
\text { upper respiratory tract infections, } \\
\text { nasopharyngitis }\end{array}$ & 2 anaphylactic reactions \\
\hline Castro et al. (71) & $\begin{array}{l}\text { ת Exacerbations (less } \\
\text { than other study) }\end{array}$ & $\begin{array}{l}\text { ת Blood and sputum } \\
\text { eosinophils, especially in } \\
\text { patients with nasal polyposis } \\
\text { Improvement in ACQ and lung } \\
\text { function }\end{array}$ & Nasopharyngitis & Pneumonia, worsening of asthma \\
\hline \multicolumn{5}{|l|}{ BENRALIZUMAB } \\
\hline $\begin{array}{l}\text { Bleecker et al. (72); } \\
\text { SIROCCO study }\end{array}$ & $\begin{array}{l}\text { ת Exacerbations } \\
- \text { ת } 45 \% \text { in Q4W } \\
\text { - 凤 } 51 \% \text { in Q8W }\end{array}$ & $\begin{array}{l}\text { 仓 FEV } \\
\text { - } 106 \mathrm{~mL} \text { Q4W } \\
\text { - } 159 \mathrm{~mL} \text { Q8W } \\
\text { Improved HRQoL }\end{array}$ & Nasopharyngitis, worsening of asthma & $\begin{array}{l}\text { Allergic granulomatous angiitis, panic } \\
\text { attack, paresthesia, injection-site } \\
\text { erythema }\end{array}$ \\
\hline $\begin{array}{l}\text { FitzGerald et al. (47); } \\
\text { CALIMA study }\end{array}$ & $\begin{array}{l}\text { ת Exacerbations } \\
\text { - 』36\% in Q4W } \\
\text { - 』2 } 28 \% \text { in Q8W }\end{array}$ & $\begin{array}{l}\text { 仓 FEV } \\
\text { - } 125 \mathrm{~mL} \text { Q4W } \\
\text { - } 116 \mathrm{~mL} \text { Q8W } \\
\text { Improve of HRQoL }\end{array}$ & Nasopharyngitis, worsening of asthma & $\begin{array}{l}\text { Urticaria, asthma, herpes zoster, chest } \\
\text { pain }\end{array}$ \\
\hline Nowak et al. (46) & ת Exacerbations & $\begin{array}{l}\text { ת Blood eosinophils } \\
\text { No improvement in lung } \\
\text { function and HRQoL }\end{array}$ & $\begin{array}{l}\text { Asthma, headache, dizziness, cough, } \\
\text { pyrexia, bronchitis, anxiety, muscle } \\
\text { spasms, and hyperhidrosis }\end{array}$ & Pyrexia, tachycardia, and anxiety \\
\hline Castro et al. (70) & $\begin{array}{l}\text { ת } 40 \% \text { Exacerbations } \\
\text { in } 100 \text { mg group, but } \\
\text { not in the } 2 \text { mg and the } \\
20 \text { mg groups }\end{array}$ & $\begin{array}{l}\text { Dose-response findings } \\
\text { 仓 Lung function and HRQoL }\end{array}$ & $\begin{array}{l}\text { Nasopharyngitis and injection-site } \\
\text { reactions }\end{array}$ & $\begin{array}{l}100 \text { mg: acute cholecystitis, herpes } \\
\text { zoster, polyarteritis nodosa, and } \\
\text { uterine leiomyoma } \\
20 \text { mg: erythema nodosum }\end{array}$ \\
\hline Laviolette et al. (53) & ת Exacerbations & & $\begin{array}{l}\text { Nasopharyngitis, nausea } \\
\text { One patient received an intravenous } \\
\text { dose of } 1 \mathrm{mg} / \mathrm{kg} \text { : chills, headache, } \\
\text { asthenia, nausea, dysgeusia, tremor, } \\
\text { dizziness, hot flush, hyperhidrosis, } \\
\text { and swelling with a decreased white } \\
\text { blood cell count, decreased neutrophil } \\
\text { count, and increase in C-reactive } \\
\text { protein }\end{array}$ & Thyroid storm with hospitalization \\
\hline
\end{tabular}


infections (44). In their trial on hypereosinophilic syndrome, Roufosse and colleagues reported the long-term safety results of $750 \mathrm{mg}$ of mepolizumab administered every 9-12 weeks. The serious adverse events comprised four deaths, although only one was considered possibly drug related by clinicians. One patient died because of angioimmunoblastic T-cell lymphoma with cardiopulmonary failure (75). Three deaths were reported in the DREAM study: one case of septic shock secondary to pancreatitis (60-year-old woman), a fatal asthma attack (56-year-old man), and a case of suicide (54-year-old man) (45).

Adverse events with benralizumab in clinical trials were rare. Laviolette et al. reported a higher rate of adverse events in the benralizumab group than in the placebo group with both subcutaneous and intravenous administration (53). The most common adverse events were nasopharyngitis and headache in the intravenous group and nasopharyngitis and nausea in the subcutaneous group. One patient receiving $1 \mathrm{mg} / \mathrm{kg}$ of benralizumab intravenously experienced 15 adverse events [chills, headache, asthenia, nausea, dysgeusia, tremors, dizziness, hot flushes, hyperhidrosis, and swelling on day 0 , with a decreased white blood cell count $\left(2.3 \times 10^{3} / \mu \mathrm{L}\right)$, decreased neutrophil count $\left(1.1 \times 10^{3} / \mu \mathrm{L}\right)$, and increased C-reactive protein level $(1.61 \mathrm{mg} /$ $\mathrm{dL}$ ) measured on day 1 after dosing]. A patient with a prior history of hyperthyroidism, who was receiving $200 \mathrm{mg}$ of benralizumab subcutaneously, experienced a thyroid storm 50 days after the first dose and 23 days after the last one. The patient was hospitalized for 8 days and subsequently completed the study. In this case, the physician considered the adverse event to be severe but not treatment related (53). Nowak and colleagues reported headache, dizziness, cough, pyrexia, bronchitis, anxiety, muscle spasms, and hyperhidrosis, with several serious events considered related to the study drug in four patients (pyrexia, tachycardia, and anxiety) (46). Castro reported adverse events in $72 \%$ of patients receiving benralizumab compared with $65 \%$ in the placebo group. The most common adverse events were nasopharyngitis and injection-site reactions (70). Safety may also be compromised by the onset of specific diseases secondary to the reduction in the eosinophil count and, therefore, potentially, the reduction in their protective effects. In this regard, no significant data have been reported or suspected in trials that explored these monoclonal antibodies. Additional data on safety $v i s-\grave{a}$-vis the reduction in the eosinophil count were added by Gleich et al., who claimed that depletion of these cells in both animal models and humans appears to have no harmful effects on health (76).

\section{Clinical Perspectives}

Considering that almost all clinical trials performed with IL-5 and IL-5Ra antagonists showed favorable results in terms of efficacy and safety, new therapeutic perspectives can be hypothesized. Despite the encouraging results, the response to these drugs must be assessed in real life, although this is unlikely, since these drugs have only recently been marketed. Nevertheless, several recent studies have reported promising results in real life, for example, the MUSCA study in patients treated with mepolizumab (68). In daily clinical practice, clinicians will be required to identify the patients who will benefit most from these targeted therapies. The fact that IL-5 and IL-5Ra antagonists have been tested targeting not only severe asthma but also other diseases (some of which are associated, e.g., nasal polyposis) could pave the way for the discovery of biomarkers that enable the clinician to chose the right drug for the patient. In fact, the choice of one drug over another could, at least for the time being, be guided by comorbidities for which a drug has been tested and another not, choosing the one that covers both diseases. Although the evaluation of comorbidities could be an interesting starting point in patients with severe eosinophilic asthma, reliable biomarkers (i.e., periostin, eosinophils, IgE, and galectin-3) that predict the response to a targeted biological therapy are urgently needed.

\section{THE PRIMARY ROLE OF BIOMARKERS}

The development of new biological therapies to target not only IL- 5 but also other $\mathrm{T}_{\mathrm{H}} 2$ cytokines including IL- 4 and IL-13 $(77,78)$ and the incoming introduction of biosimilar drugs (79) raise the question of which therapy is best suited to a specific patient. The answer to this question may lie in the identification of biomarkers that predict therapeutic responses. An ideal biomarker should be easy to collect and evaluate, non-invasive, inexpensive, and sensitive (80). Many studies have proposed biomarkers for the management of asthmatic patients, including serum total IgE levels (IgEs) (81), exhaled nitric oxide (FeNO), blood and sputum eosinophil count $(82,83)$, and the possible role of galectin- 3 obtained by bronchial biopsy in early studies (84) and now less invasively in serum (85) or serum periostin (86) as biomarkers of $\mathrm{T}_{\mathrm{H}} 2$-induced upper airway inflammation. Biomarkers are urgently needed to assign the most appropriate therapeutic strategy to a specific patient, according to the underlying asthmatic mechanism of inflammation. Consequently, therapy could switch from a "one size fits all" approach (the clinician prescribes a drug and, if this fails, a new prescription is made) to an approach based on "personalized medicine" or "precision medicine," where a biomarker could help physicians to phenotype patients and choose the most appropriate therapy (87-90).

\section{CONCLUSION}

For many years, eosinophilic inflammation has been considered a predominant mechanism in the development of asthma. IL-5 has been evaluated as a possible therapeutic target solely for its role in the development and action of eosinophils. Although initial trials results are not encouraging, it seems that choosing the optimal candidate, i.e., one with severe asthma and a high serum eosinophil count, could lead to a reduction in the frequency of exacerbations. The better results observed in patients with high eosinophil counts have led several authors to suggest $>300-400 / \mu \mathrm{L}$ as a cutoff. Therefore, based on clinical trial results, it will be necessary to screen patients before prescription of antiIL-5 and IL-5Ra drugs to choose the right patient for the right drug, i.e., one who is more likely to respond to a specific therapy. Eosinophils are currently the only suitable biomarker for these drugs, and every effort should be made to discover new biomarkers that enable more personalized and precise prescription. The role of biomarkers will become fundamental, leading clinicians to choose the best anti-IL-5 and IL-5Ra drugs for their patients. 


\section{AUTHOR CONTRIBUTIONS}

DB and MF contributed equally to the conception and design of the study. DB, MF, FP, and GV drafted the manuscript. GC and GP approved the version to be published.

\section{REFERENCES}

1. Global Initiative for the Management of Asthma 2015. (2016). Available from: www.ginasthma.org

2. Woodruff PG, Modrek B, Choy DF, Jia G, Abbas AR, Ellwanger A, et al. T-helper type 2-driven inflammation defines major subphenotypes of asthma. Am J Respir Crit Care Med (2009) 180:388-95. doi:10.1164/rccm.2009030392OC

3. De Ferrari L, Chiappori A, Bagnasco D, Riccio AM, Passalacqua G, Canonica GW. Molecular phenotyping and biomarker development: are we on our way towards targeted therapy for severe asthma? Expert Rev Respir Med (2016) 10:9-38. doi:10.1586/17476348.2016.1111763

4. Wenzel S. Severe asthma: from characteristics to phenotypes to endotypes. Clin Exp Allergy (2012) 42:650-8. doi:10.1111/j.1365-2222.2011.03929

5. Fitzpatrick AM, Teague WG, Meyers DA, Peters SP, Li X, Li H, et al. Heterogeneity of severe asthma in childhood: confirmation by cluster analysis of children in the National Institutes of Health/National Heart, Lung, and Blood Institute Severe Asthma Research Program. JAllergy Clin Immunol (2011) 127:382-9. doi:10.1016/j.jaci.2010.11.015

6. Moore WC, Meyers DA, Wenzel SE, Teague WG, Li H, Li X, et al. Identification of asthma phenotypes using cluster analysis in the Severe Asthma Research Program. Am J Respir Crit Care Med (2010) 181:315-23. doi:10.1164/ rccm.200906-0896OC

7. Schatz M, Hsu JW, Zeiger RS, Chen W, Dorenbaum A, Chipps BE, et al. Phenotypes determined by cluster analysis in severe or difficult-to-treat asthma. J Allergy Clin Immunol (2014) 133:1549-56. doi:10.1016/j.jaci.2013.10.006

8. Woodruff PG, Boushey HA, Dolganov GM, Barker CS, Yang YH, Donnelly $S$, et al. Genome-wide profiling identifies epithelial cell genes associated with asthma and with treatment response to corticosteroids. Proc Natl Acad Sci U S A (2007) 104:15858-63. doi:10.1073/pnas.0707413104

9. Lloyd CM, Hessel EM. Functions of T cells in asthma: more than just $\mathrm{T}(\mathrm{H}) 2$ cells. Nat Rev Immunol (2010) 10(12):838-48. doi:10.1038/nri2870

10. Varricchi G, Bagnasco D, Borriello F, Heffler E, Canonica GW. Interleukin-5 pathway inhibition in the treatment of eosinophilic respiratory disorders: evidence and unmet needs. Curr Opin Allergy Clin Immunol (2016) 16(2):186-200. doi:10.1097/ACI.000000000000025

11. Broughton SE, Nero TL, Dhagat U, Kan WL, Hercus TR, Tvorogov D, et al. The beta receptor family - structural insights and their functional implications. Cytokine (2015) 74:247-58. doi:10.1016/j.cyto.2015.02.005

12. van Rijt L, von Richthofen H, van Ree R. Type 2 innate lymphoid cells: at the cross-roads in allergic asthma. Semin Immunopathol (2016) 38(4):483-96. doi:10.1007/s00281-016-0556-2

13. Larose MC, Turcotte C, Chouinard F, Ferland C, Martin C, Provost V, et al. Mechanisms of human eosinophil migration induced by the combination of IL-5 and the endocannabinoid 2-arachidonoyl-glycerol. J Allergy Clin Immunol (2014) 133(5):1480-2. doi:10.1016/j.jaci.2013.12.1081

14. Busse WW, Holgate ST, Wenzel SW, Klekotka P, Chon Y, Feng J, et al. Biomarker profiles in asthma with high vs low airway reversibility and poor disease control. Chest (2015) 148(6):1489-96. doi:10.1378/chest.14-2457

15. Thomson NC. Novel approaches to the management of noneosinophilic asthma. Ther Adv Respir Dis (2016) 10(3):211-34. doi:10.1177/1753465816632638

16. Menzella F, Lusuardi M, Galeone C, Taddei S, Zucchi L. Profile of anti-IL-5 $\mathrm{mAb}$ mepolizumab in the treatment of severe refractory asthma and hypereosinophilic diseases. J Asthma Allergy (2015) 8:105-14. doi:10.2147/JAA. S40244

17. Nussbaum JC, Van Dyken SJ, von Moltke J, Cheng LE, Mohapatra A, Molofsky AB, et al. Type 2 innate lymphoid cells control eosinophil homeostasis. Nature (2013) 502:245-8. doi:10.1038/nature12526

18. Garcia G, Taillé C, Laveneziana P, Bourdin A, Chanez P, Humbert M. Antiinterleukin-5 therapy in severe asthma. Eur Respir Rev (2013) 22(129):251-7. doi:10.1183/09059180.00004013

\section{ACKNOWLEDGMENTS}

This paper was partially supported by ARMIA (Associazione Ricerca Malattie Immunologiche e Allergiche), Genova, Italy.

19. Parulekar AD, Diamant $Z$, Hanania NA. Role of $\mathrm{T} 2$ inflammation biomarkers in severe asthma. Curr Opin Pulm Med (2016) 22(1):59-68. doi:10.1097/ MCP.0000000000000231

20. Schollaert KL, Stephens MR, Gray JK, Fulkerson PC. Generation of eosinophils from cryopreserved murine bone marrow cells. PLoS One (2014) 9(12):e116141. doi:10.1371/journal.pone.0116141

21. Manuyakorn W, Howarth PH, Holgate ST. Airway remodelling in asthma and novel therapy. Asian Pac J Allergy Immunol (2013) 31(1):3-10.

22. Broughton SE, Dhagat U, Hercus TR, Nero TL, Grimbaldeston MA, Bonder CS, et al. The GM-CSF/IL-3/IL-5 cytokine receptor family: from ligand recognition to initiation of signaling. Immunol Rev (2012) 250(1):277-302. doi:10.1111/j.1600-065X.2012.01164.X

23. Eberl G, Colonna M, Di Santo JP, McKenzie AN. Innate lymphoid cells. Innate lymphoid cells: a new paradigm in immunology. Science (2015) 348(6237):aaa6566. doi:10.1126/science.aaa6566

24. Monticelli LA, Sonnenberg GF, Abt MC, Alenghat T, Ziegler CG, Doering TA, et al. Innate lymphoid cells promote lung-tissue homeostasis after infection with influenza virus. Nat Immunol (2011) 12:1045-54. doi:10.1031/ni.2131

25. Spits H, Artis D, Colonna M, Diefenbach A, Di Santo JP, Eberl G, et al. Innate lymphoid cells - a proposal for uniform nomenclature. Nat Rev Immunol (2013) 13(2):145-9. doi:10.1038/nri3365

26. Sonnenberg GF, Sonnenberg GF, Monticelli LA, Alenghat T, Fung TC, Hutnick NA, et al. Innate lymphoid cells promote anatomical containment of lymphoid-resident commensal bacteria. Science (2012) 336:1321-5. doi:10.1126/science.1222551

27. Kim HY, Umetsu DT, Dekruyff RH. Innate lymphoid cells in asthma: will they take your breath away? Eur J Immunol (2016) 46(4):795-806. doi:10.1002/ eji.201444557

28. Moro K, Yamada T, Tanabe M, Takeuchi T, Ikawa T, Kawamoto H, et al. Innate production of TH2 cytokines by adipose tissue-associated c-Kit+Sca-1+ lymphoid cells. Nature (2010) 463:540-4. doi:10.1038/nature08636

29. Spits H, Di Santo JP. The expanding family of innate lymphoid cells: regulators and effectors of immunity and tissue remodeling. Nat Immunol (2011) 12:21-7. doi:10.1038/ni.1962

30. Liang HE, Reinhardt RL, Bando JK, Sullivan BM, Ho IC, Locksley RM. Divergent expression patterns of IL- 4 and IL-13 define unique functions in allergic immunity. Nat Immunol (2012) 13:58-66. doi:10.1038/ni.2182

31. Wong SH, Walker JA, Jolin HE, Drynan LF, Hams E, Camelo A, et al. Transcription factor ROR $\alpha$ is critical for nuocyte development. Nat Immunol (2012) 13:229-36. doi:10.1038/ni.2208

32. Klein Wolterink RG, Kleinjan A, van Nimwegen M, Bergen I, de Bruijn M, Levani Y, et al. Pulmonary innate lymphoid cells are major producers of IL-5 and IL-13 in murine models of allergic asthma. Eur J Immunol (2012) 42(5):1106-16. doi:10.1002/eji.201142018

33. Heinecke JW. Eosinophil-dependent bromination in the pathogenesis of asthma. J Clin Invest (2000) 105(10):1331-2. doi:10.1172/JCI10072

34. Kim HY, DeKruyff RH, Umetsu DT. The many paths to asthma: phenotype shaped by innate and adaptive immunity. Nat Immunol (2010) 11(7):577-84. doi:10.1038/ni.1892

35. Kim S, Marigowda G, Oren E, Israel E, Wechsler ME. Mepolizumab as a steroid-sparing treatment option in patients with Churg-Strauss syndrome. J Allergy Clin Immunol (2010) 125:1336-43. doi:10.1016/j.jaci. 2010.03.028

36. Bagnasco D, Ferrando M, Caminati M, Bragantini A, Puggioni F, Varricchi G, et al. Targeting interleukin-5 or interleukin-5R $\alpha$ : safety considerations. Drug Saf (2017) 40(7):559-70. doi:10.1007/s40264-017-0522-5

37. Shirasaki H, Himi T. Role of cysteinyl leukotrienes in allergic rhinitis. $A d v$ Otorhinolaryngol (2016) 77:40-5. doi:10.1159/00044187

38. DeKruyff RH, Yu S, Kim HY, Umetsu DT. Innate immunity in the lung regulates the development of asthma. Immunol Rev (2014) 260:235-48. doi:10.1111/imr.12187 
39. Ray A, Oriss TB, Wenzel SE. Emerging molecular phenotypes of asthma. Am J Physiol Lung Cell Mol Physiol (2015) 308:L130-40. doi:10.1152/ ajplung.00070.2014

40. Bandeira-Melo C, Bozza P, Weller P. The cellular biology of eosinophil eicosanoid formation and function. J Allergy Clin Immunol (2002) 109(3):393-400. doi:10.1067/mai.2002.121529

41. Rosenberg HF, Dyer KD, Foster PS. Eosinophils: changing perspectives in health and disease. Nat Rev Immunol (2013) 13(1):9-22. doi:10.1038/nri3341

42. Pavord ID, Hilvering B, Shrimanker R. Emerging biologics in severe asthma. Immunol Allergy Clin North Am (2016) 36(3):609-23. doi:10.1016/j. iac.2016.04.001

43. Durrani SR, Viswanathan RK, Busse WW. What effect does asthma treatment have on airway remodeling? Current perspectives. J Allergy Clin Immunol (2011) 128(3):439-48; quiz 449-50. doi:10.1016/j.jaci.2011.06.002

44. Ortega HG, Liu MC, Pavord ID, Brusselle GG, FitzGerald JM, Chetta A, et al. Mepolizumab treatment in patients with severe eosinophilic asthma. N Engl $J$ Med (2014) 371(13):1198-207. doi:10.1056/NEJMoa1403290

45. Pavord ID, Korn S, Howarth P, Bleecker ER, Buhl R, Keene ON, et al. Mepolizumab for severe eosinophilic asthma (DREAM): a multicentre, double-blind, placebo-controlled trial. Lancet (2012) 380(9842):651-9. doi:10.1016/S0140-6736(12)60988-X

46. Nowak RM, Parker JM, Silverman RA, Rowe BH, Smithline H, Khan F, et al. A randomized trial of benralizumab, an antiinterleukin 5 receptor $\alpha$ monoclonal antibody, after acute asthma. Am J Emerg Med (2015) 33(1):14-20. doi:10.1016/j.ajem.2014.09.036

47. FitzGerald JM, Bleecker ER, Nair P, Korn S, Ohta K, Lommatzsch M, et al. Benralizumab, an anti-interleukin-5 receptor $\alpha$ monoclonal antibody, as add-on treatment for patients with severe, uncontrolled, eosinophilic asthma (CALIMA): a randomised, double-blind, placebo-controlled phase 3 trial. Lancet (2016) 388(10056):2128-41. doi:10.1016/S0140-6736(16)31322-8

48. Abonia JP, Putnam PE. Mepolizumab in eosinophilic disorders. Expert Rev Clin Immunol (2011) 7:411-7. doi:10.1586/eci.11.27

49. Keating GM. Mepolizumab: first global approval. Drugs (2015) 75(18):2163-9. doi:10.1007/s40265-015-0513-8

50. Hart TK, Cook RM, Zia-Amirhosseini P, Minthorn E, Sellers TS, Maleeff BE, et al. Preclinical efficacy and safety of mepolizumab (SB-240563), a humanized monoclonal antibody to IL-5, in cynomolgus monkeys. J Allergy Clin Immunol (2001) 108:250-7. doi:10.1067/mai.2001.116576

51. Egan RW, Athwal D, Bodmer MW, Carter JM, Chapman RW, Chou CC, et al. Effect of Sch 55700, a humanized monoclonal antibody to human interleukin-5, on eosinophilic responses and bronchial hyperreactivity. Arzneimittelforschung (1999) 49:779-90. doi:10.1055/s-0031-1300502

52. Spergel JM, Rothenberg ME, Collins MH, Furuta GT, Markowitz JE, Fuchs G 3rd. Reslizumab in children and adolescents with eosinophilic esophagitis: results of a double-blind, randomized, placebo-controlled trial. J Allergy Clin Immunol (2012) 129(2):456-63, 463.e1-3. doi:10.1016/j.jaci.2011.11.044

53. Laviolette M, Gossage DL, Gauvreau G, Leigh R, Olivenstein R, Katial R, et al. Effects of benralizumab on airway eosinophils in asthmatic patients with sputum eosinophilia. J Allergy Clin Immunol (2013) 132(5):1086-96.e5. doi:10.1016/j.jaci.2013.05.020

54. Hilvering B, Xue L, Pavord ID. Evidence for the efficacy and safety of anti-interleukin-5 treatment in the management of refractory eosinophilic asthma. Ther Adv Respir Dis (2015) 9(4):135-45. doi:10.1177/175346581 5581279

55. Kolbeck R, Kozhich A, Koike M, Peng L, Andersson CK, Damschroder MM, et al. MEDI-563, a humanized anti-IL-5 receptor alpha mAb with enhanced antibody-dependent cell-mediated cytotoxicity function. JAllergy Clin Immunol (2010) 125:1344-53. doi:10.1016/j.jaci.2010.04.004

56. Ghazi A, Trikha A, Calhoun WJ. Benralizumab - a humanized mAb to IL-5R $\alpha$ with enhanced antibody-dependent cell-mediated cytotoxicity - a novel approach for the treatment of asthma. Expert Opin Biol Ther (2012) 12(1):113-8. doi:10.1517/14712598.2012.642359

57. Brightling CE, Bleecker ER, Panettieri RA Jr, Bafadhel M, She D, Ward CK, et al. Benralizumab for chronic obstructive pulmonary disease and sputum eosinophilia: a randomised, double-blind, placebo-controlled, phase 2a study. Lancet Respir Med (2014) 2(11):891-901. doi:10.1016/S2213-2600(14) 70187-0

58. Akutsu I, Kojima T, Kariyone A, Fukuda T, Makino S, Takatsu K. Antibody against interleukin-5 prevents antigen-induced eosinophil infiltration and bronchial hyperreactivity in the guinea pig airways. Immunol Lett (1995) 45(1-2):109-16. doi:10.1016/0165-2478(94)00241-I

59. Leckie MJ. Anti-interleukin-5 monoclonal antibodies: preclinical and clinical evidence in asthma models. Am J Respir Med (2003) 2(3):245-59. doi:10.1007/ BF03256653

60. Leckie MJ, ten Brinke A, Khan J, Diamant Z, O'Connor BJ, Walls $\mathrm{CM}$, et al. Effects of an interleukin-5 blocking monoclonal antibody on eosinophils, airway hyper-responsiveness, and the late asthmatic response. Lancet (2000) 356(9248):2144-8. doi:10.1016/S0140-6736(00) 03496-6

61. Flood-Page PT, Menzies-Gow AN, Kay AB, Robinson DS. Eosinophil's role remains uncertain as anti-interleukin-5 only partially depletes numbers in asthmatic airway. Am J Respir Crit Care Med (2003) 167(2):199-204. doi:10.1164/rccm.200208-789OC

62. Kay AB, Menzies-Gow A. Eosinophils and interleukin-5: the debate continues. Am J Respir Crit Care Med (2003) 167(12):1586-7. doi:10.1164/rccm. 2304001

63. Flood-Page P, Swenson C, Faiferman I, Matthews J, Williams M, Brannick L, et al. A study to evaluate safety and efficacy of mepolizumab in patients with moderate persistent asthma. Am J Respir Crit Care Med (2007) 176(11): 1062-71. doi:10.1164/rccm.200701-085OC

64. Bel EH, Wenzel SE, Thompson PJ, Prazma CM, Keene ON, Yancey SW, et al. Oral glucocorticoid-sparing effect of mepolizumab in eosinophilic asthma. N Engl J Med (2014) 371(13):1189-97. doi:10.1056/NEJMoa1403291

65. Haldar P, Brightling CE, Hargadon B, Gupta S, Monteiro W, Sousa A, et al. Mepolizumab and exacerbations of refractory eosinophilic asthma. $N$ Engl $J$ Med (2009) 360(10):973-84. doi:10.1056/NEJMoa0808991

66. Powell C, Milan SJ, Dwan K, Bax L, Walters N. Mepolizumab versus placebo for asthma. Cochrane Database Syst Rev (2015) 27(7):CD010834. doi:10.1002/14651858.CD010834

67. Liu Y, Zhang S, Li DW, Jiang SJ. Efficacy of anti-interleukin-5 therapy with mepolizumab in patients with asthma: a meta-analysis of randomized placebo-controlled trials. PLoS One (2013) 8(3):e59872. doi:10.1371/journal. pone. 0059872

68. Chupp GL, Bradford ES, Albers FC, Bratton DJ, Wang-Jairaj J, Nelsen LM, et al. Efficacy of mepolizumab add-on therapy on health-related quality of life and markers of asthma control in severe eosinophilic asthma (MUSCA): a randomised, double-blind, placebo-controlled, parallel-group, multicentre, phase 3b trial. Lancet Respir Med (2017) 5(5):390-400. doi:10.1016/ S2213-2600(17)30125-X

69. Castro M, Zangrilli J, Wechsler ME, Bateman ED, Brusselle GG, Bardin P, et al. Reslizumab for inadequately controlled asthma with elevated blood eosinophil counts: results from two multicentre, parallel, double-blind, randomised, placebo-controlled, phase 3 trials. Lancet Respir Med (2015) 3(5):355-66. doi:10.1016/S2213-2600(15)00042-9

70. Castro M, Wenzel SE, Bleecker ER, Pizzichini E, Kuna P, Busse WW, et al. Benralizumab, an anti-interleukin 5 receptor $\alpha$ monoclonal antibody, versus placebo for uncontrolled eosinophilic asthma: a phase $2 \mathrm{~b}$ randomised dose-ranging study. Lancet Respir Med (2014) 2(11):879-90. doi:10.1016/ S2213-2600(14)70201-2

71. Castro M, Mathur S, Hargreave F, Boulet LP, Xie F, Young J, et al. Reslizumab for poorly controlled, eosinophilic asthma: a randomized, placebo-controlled study. Am J Respir Crit Care Med (2011) 184(10):1125-32. doi:10.1164/ rccm.201103-0396OC

72. Bleecker ER, FitzGerald JM, Chanez P, Papi A, Weinstein SF, Barker P, et al. Efficacy and safety of benralizumab for patients with severe asthma uncontrolled with high-dosage inhaled corticosteroids and long-acting $\beta 2$-agonists (SIROCCO): a randomised, multicentre, placebo-controlled phase 3 trial. Lancet (2016) 388(10056):2115-27. doi:10.1016/S0140-6736(16) 31324-1

73. Nair P, Pizzichini MM, Kjarsgaard M, Inman MD, Efthimiadis A, Pizzichini E, et al. Mepolizumab for prednisone-dependent asthma with sputum eosinophilia. N Engl J Med (2009) 360(10):985-93. doi:10.1056/NEJMoa0 805435

74. Passalacqua G, Matucci A, Vultaggio A, Bagnasco D, Mincarini M, Maggi E, et al. The safety of monoclonal antibodies in asthma. Expert Opin Drug Saf (2016) 15(8):1087-95. doi:10.1080/14740338.2016.1186641

75. Roufosse FE, Kahn JE, Gleich GJ, Schwartz LB, Singh AD, Rosenwasser LJ, et al. Long-term safety of mepolizumab for the treatment of hypereosinophilic 
syndromes. J Allergy Clin Immunol (2013) 131(2):461-7.e1-5. doi:10.1016/j. jaci.2012.07.055

76. Gleich GJ, Klion AD, Lee JJ, Weller PF. The consequences of not having eosinophils. Allergy (2013) 68(7):829-35. doi:10.1111/all.12169

77. Fajt ML, Wenzel SE. Asthma phenotypes and the use of biologic medications in asthma and allergic disease: the next steps toward personalized care. JAllergy Clin Immunol (2015) 135(2):299-310. doi:10.1016/j.jaci.2014. 12.1871

78. Bagnasco D, Ferrando M, Varricchi G, Passalacqua G, Canonica GW. A critical evaluation of anti-IL-13 and IL-4 strategy in severe asthma. Int Arch Allergy Immunol (2016) 170(2):122-31. doi:10.1159/000447692

79. Ferrando M, Bagnasco D, Braido F, Varricchi G, Canonica GW. Biosimilars in allergic diseases. Curr Opin Allergy Clin Immunol (2016) 16(1):68-73. doi:10.1097/ACI.0000000000000226

80. Rossi R, De Palma A, Benazzi L, Riccio AM, Canonica GW, Mauri P. Biomarker discovery in asthma and COPD by proteomic approaches. Proteomics Clin Appl (2014) 8:901-15. doi:10.1002/prca.201300108

81. Hanania NA, Wenzel S, Rosen K, Hsieh HJ, Mosesova S, Choy DF, et al. Exploring the effects of omalizumab in allergic asthma. An analysis of biomarkers in the EXTRA study. Am J Respir Crit Care Med (2013) 187:804-11. doi:10.1164/rccm.201208-1414OC

82. Mukherjee M, Sehmi R, Nair P. Anti-IL5 therapy for asthma and beyond. World Allergy Organ J (2014) 7(1):32. doi:10.1186/1939-4551-7-32

83. Buhl R, Korn S, Menzies-Gow A, Aubier M, Chapman KR, Canonica GW, et al. Assessing biomarkers in a real-world severe asthma study (ARIETTA). Respir Med (2016) 115:7-12. doi:10.1016/j.rmed.2016.04.001

84. Mauri P, Riccio AM, Rossi R, Di Silvestre D, Benazzi L, De Ferrari L, et al. Proteomics of bronchial biopsies: galectin-3 as a predictive biomarker of airway remodelling modulation in omalizumab-treated severe asthma patients. Immunol Lett (2014) 162:2-10. doi:10.1016/j.imlet.2014.08.010

85. Riccio AM, Mauri P, De Ferrari L, Rossi R, Di Silvestre D, Benazzi L, et al. Galectin-3: an early predictive biomarker of modulation of airway remodeling in patients with severe asthma treated with omalizumab for 36 months. Clin Transl Allergy (2017) 7:6. doi:10.1186/s13601-017-0143-1

86. Corren J, Lemanske RF, Hanania NA, Korenblat PE, Parsey MV, Arron JR, et al. Lebrikizumab treatment in adults with asthma. N Engl J Med (2011) 365:1088-98. doi:10.1056/NEJMoa1106469

87. Bagnasco D, Ferrando M, Bernardi S, Passalacqua G, Canonica GW. The path to personalized medicine in asthma. Expert Rev Respir Med (2016) 10(9):957-65. doi:10.1080/17476348.2016.1205490

88. Ferrando M, Bagnasco D, Varricchi G, Bernardi S, Bragantini A, Passalacqua $\mathrm{G}$, et al. Personalized medicine in allergy. Allergy Asthma Immunol Res (2017) 9(1):15-24. doi:10.4168/aair.2017.9.1.15

89. Riccio AM, De Ferrari L, Chiappori A, Ledda S, Passalacqua G, Melioli G, et al. Molecular diagnosis and precision medicine in allergy management Clin Chem Lab Med (2016) 54(11):1705-14. doi:10.1515/cclm-20160007

90. Akdis CA, Ballas ZK. Precision medicine and precision health: building blocks to foster a revolutionary health care model. J Allergy Clin Immunol (2016) 137(5):1359-61. doi:10.1016/j.jaci.2016.03.020

Conflict of Interest Statement: GC has been a member of advisory boards and speaker at scientific meetings for GSK, Teva, Sanofi, Roche, Novartis, and Astra Zeneca. GP has been a consultant/speaker for ALK-Abelló, AstraZeneca, Lofarma, Novartis, and Stallergenes-Greer.

Copyright @ 2017 Bagnasco, Ferrando, Varricchi, Puggioni, Passalacqua and Canonica. This is an open-access article distributed under the terms of the Creative Commons Attribution License (CC BY). The use, distribution or reproduction in other forums is permitted, provided the original author(s) or licensor are credited and that the original publication in this journal is cited, in accordance with accepted academic practice. No use, distribution or reproduction is permitted which does not comply with these terms. 